\title{
A REVIEW OF BIOMASS ENERGY: INDIAN SCENARIO
}

\author{
Shaikh Mohammed Shoeb ${ }^{1}$, Shaikh Shoeb², Mohammad Munwaroddin ${ }^{3}$, Syed Sibghatullah Quadri ${ }^{4}$ \\ ${ }^{I}$ Student, Dept. of Electrical Electronics \& Power, Jawaharlal Nehru Engg College (J.N.E.C), \\ Aurangabad Maharashtra, India \\ ${ }^{2}$ Student, Dept. of Electrical Electronics \& Power, Jawaharlal Nehru Engg College (J.N.E.C), \\ Aurangabad Maharashtra, India \\ ${ }^{3}$ Student, Dept. of Electrical Electronics \& Power, Jawaharlal Nehru Engg College (J.N.E.C), \\ Aurangabad Maharashtra, India \\ ${ }^{4}$ Student, Dept. of Electrical Electronics \& Power, Jawaharlal Nehru Engg College (J.N.E.C), \\ Aurangabad Maharashtra, India
}

\begin{abstract}
This paper contains detailed discussion about biomass energy sources such as, bagasse, municipal solid waste, agricultural waste etc. The sources of biomass is described in along with the classifications. The types of biogas power plant their construction and working. The generation of electricity by biogas is mentioned. The advantages of biomass energy is mentioned in this paper. The suggestions for energy policy for biomass energy is given. The detailed analysis of biomass cost compared to other types of the sources. The statewide potential, installed capacity of biogas capacity is described in this paper. The components of biomass available in India is explained in this paper. The other benefits of biogas is also mentioned. The Indian scenario of biomass energy source is described. Also future scope of biomass energy is discussed.
\end{abstract}

Keywords: Biomass, Biogas, Bagasse, MSW, Fermentation, anaerobic, digester, Electricity, energy, Energy policy

\section{INTRODUCTION}

Bio mass is carbonaceous organic waste from animals and plants, it generally refers to the agricultural waste likes talks, stems, husks, shells etc. It also contains combination of waste from food industries, animal waste, Municipal wastes and sewage. It is considered as renewable energy source because it can be replenished by growing new crops. It is a better alternative than the coal. Bio mass is used in India for cooking and heating mainly in the rural areas. However due to lack of awareness about the proper and efficient use of biomass it is not used up to its full potential. The same is applicable for urban areas, here the municipal solid waste is generated in huge quantities but a very little amount of it is used properly. India is a developing country and every day millions of tons of such waste is generated. What is needed the most, is the proper waste management and waste to energy policy. This will not only help to handle the waste properly but also generate electricity along with other benefits.

Now let us see in detail the sources of biomass, production of biogas, production of electricity, cost of per unit, pollution control, waste management, and other advantages.

\subsection{Biomass Sources}

Biomass sources can be any organic waste from animal, plants and even aquatic. India is a huge agricultural based country, so agricultural waste is in abundance. Also there are many forests in India which provide with firewood. The sources are classified as
(1) Forest Waste-wood, timber, sawdust, tree branches leave etc.

(2) Agricultural Waste-Stalks, stems, fibers, rice husks, coconut shells, jute sticks coffee husks, bagasse etc.

(3) Animal waste-cow dung, poultry waste, sewage, etc.

(4) Aquatic waste-algae, water hyacinth, aquatic weeds, sea grass, kelp, coral, etc.

(5) Other waste-waste from food processing industries, municipal wastes, industrial wastes, etc.

\section{BREAKUP OF INDIA'S INSTALLED BIOMASS POWER CAPACITY}

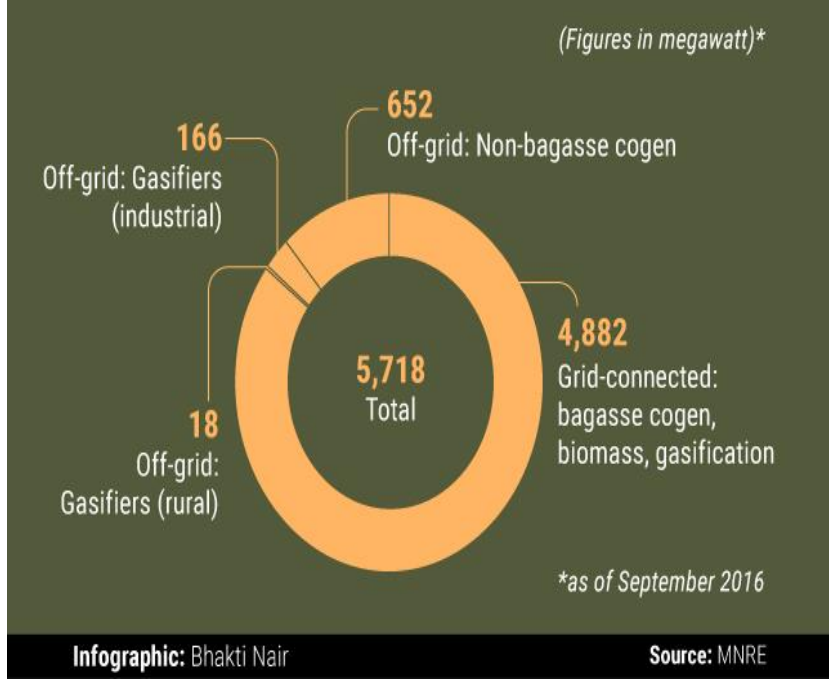




\subsection{Bio Gas Production}

Biogas typically refers to a mixture of different gases produced by the breakdown of organic matter in the absence of oxygen. Biogas can be produced from raw materials such as agricultural waste, manure, municipal waste, plant material, sewage, green waste or food waste. Biogas is a renewable energy source.

It is produced by two methods

\section{1) Fixed dome type}

2) Floating Dome type

\section{Fixed Dome Type}

Pin this type a dome is constructed below the ground level. With the help of bricks. The Area under the Dome is called as digestor. on the ground level there are two tanks viz. mixing tanks and overflow tank. In the mixing tank the slurry (Mix of bio waste) and water and then it is fed to the digester. An outlet is used to collect the bio gas at the top of the dome.

\section{FIXED DOME TYPE BIOGAS PLANT}

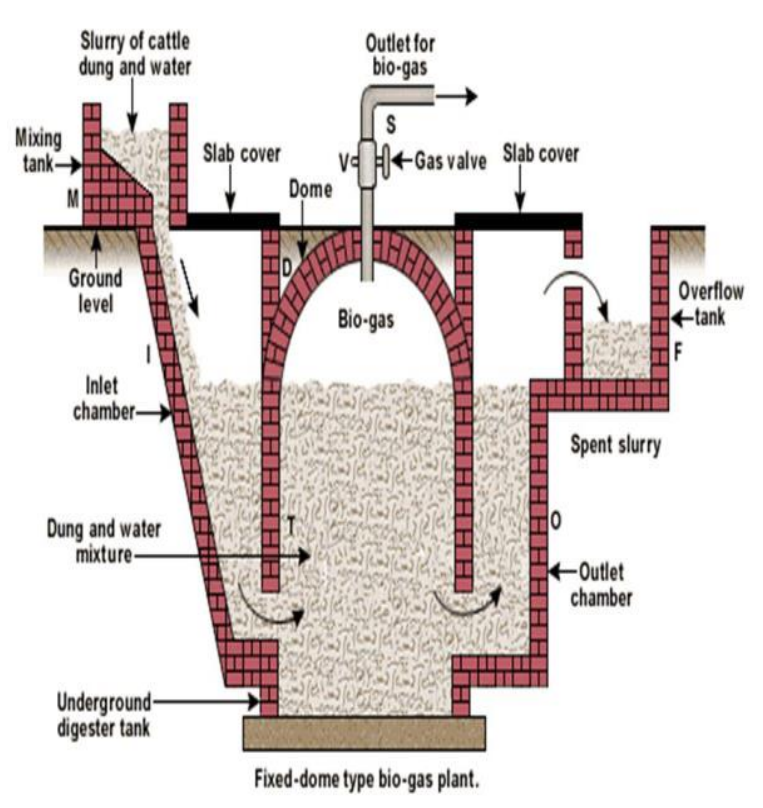

\section{Floating Dome Type}

This type is much similar to the fixed dome type the only difference is that the dome is replaced by the gas holder and a gas controlled valve is provided to control the pressure. This type of dome is economical as compared to fixed dome type.

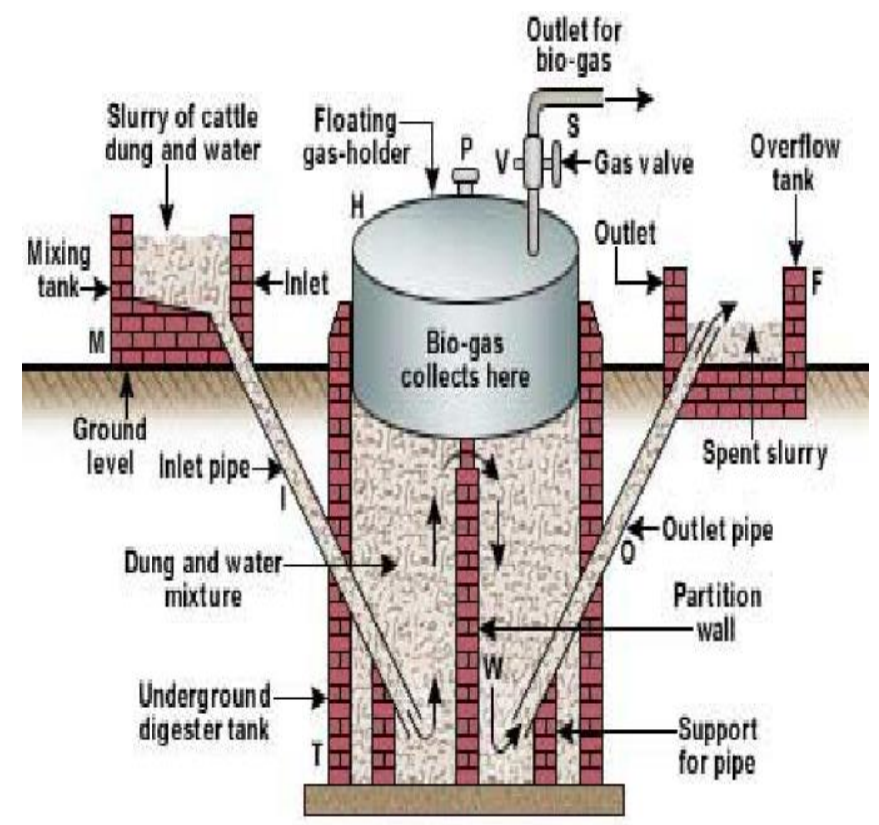

Floating gas-holder type bio-gas plant.

\section{Working of Biogas Plant}

Initially the waste and water is then being mixed to make slurry in the mixing tank. This slurry enters in the digester tank is left for about two months for fermentation. The anaerobic micro-organism are responsible for fermentation which produce biogas. And it is collected in dome of fixed variable type and in the variable dome type the produced gas is collected into the gas holding tank. The gas exerts the large pressure on the slurry and forced it go in the overflow tank. The biogas taken out from the chamber through a pipe and further used for generation of electricity, heat, and cooking etc. The residue of the plant is used as manure because it is rich in nitrogen and phosphorus.

\section{Generation of Electricity}

In recent year's energy consumption has been increasing at relatively fast rate due to population and industrialization growth. And also with rapid urbanization and improving living of standard demand of energy is increasing day by day. Most of the power is generated in India is thermal power plant i.e. (by coal) hence which tend to increase in carbon percent and pollution too. The biomass power plant is similar to the thermal power plant nut the major difference is that the coal is replaced by the biogas due to which pollution is get controlled. The gas used is fed by the gasification process in which the conversion of biomass into combustible gas mixture by the partial oxidation of biomass at high temperature in the range 800-900 LC. Then the calorific value gas produced can be burnt directly or fed to the boilers. 


\section{Advantages of Biomass}

- Rural electrification cab be made possible.

- Reducing poverty by providing job opportunities at rural areas.

- Overcoming the power deficits of agricultural sector.

- Generation biogas and satisfying the demand for cooking gas at consumer level itself.

- $\quad$ Projecting India as 'Green Nation'.

- Reducing carbon footprint.

- Generating funds through CDM (clean development mechanism of Kyoto protocol.

- Providing empowerment to the farmers.

- Production of fertilizer which will reduce soil pollution generally caused by chemical fertilizer.

- Increased productivity of crops.

- Giving boost to national economy.

\section{Energy Policies for Biomass}

1. Making bagasse cogeneration mandatory in every sugar factory.

2. Use of rice husk gasifier in rural areas like successful model in Bihar which uses off grid power using biomass,

3. National program for bio energy to execute projects in rural areas.

4. Using of animal waste to produce biomass.

5. Subsidies to promote the use of biomass energy.

6. Conducting awareness program.

7. Commissioning a new independent body (like BEE) to oversee and monitor biomass projects.

\begin{tabular}{|c|c|c|c|c|c|c|c|}
\hline \multicolumn{8}{|c|}{ Potential, Installed \& Under Implementation (31.12.2012) } \\
\hline \multirow{2}{*}{$\begin{array}{l}\text { Si. } \\
\text { No. }\end{array}$} & \multirow[b]{2}{*}{ State } & \multicolumn{2}{|c|}{ Potential } & \multicolumn{2}{|c|}{$\begin{array}{l}\text { Projects } \\
\text { Installed }\end{array}$} & \multicolumn{2}{|c|}{$\begin{array}{l}\text { Projects under } \\
\text { Implementation }\end{array}$} \\
\hline & & Nos. & $\begin{array}{l}\text { Total } \\
\text { Capacity } \\
\text { (MW) }\end{array}$ & Nos. & $\begin{array}{l}\text { Capacity } \\
\text { (MW) }\end{array}$ & Nos. & $\begin{array}{l}\text { Capacity } \\
\text { (MW) }\end{array}$ \\
\hline 1 & $\begin{array}{l}\text { Andhra } \\
\text { Pradesh }\end{array}$ & 497 & 560.18 & 64 & 192.63 & 18 & 62.05 \\
\hline 2 & $\begin{array}{l}\text { Arunachal } \\
\text { Pradesh }\end{array}$ & 550 & 1328.68 & 104 & 79.54 & 117 & 46.97 \\
\hline 3 & Assam & 119 & 238.69 & 5 & 31.11 & 4 & 15.00 \\
\hline 4 & Bihar & 95 & 213.25 & 21 & 61.30 & 7 & 22.60 \\
\hline 5 & Chattisgarh & 184 & 993.11 & 7 & 20.25 & 6 & 147.00 \\
\hline 6 & Goa & 6 & 6.50 & 1 & 0.05 & - & - \\
\hline 7 & Gujarat & 292 & 196.97 & 5 & 15.60 & - & \\
\hline 8 & Haryana & 33 & 110.05 & 7 & 70.10 & 2 & 3.40 \\
\hline 9 & $\begin{array}{l}\text { Himachal } \\
\text { Pradesh }\end{array}$ & 536 & 2267.81 & 131 & 466.37 & 28 & 106.85 \\
\hline 10 & J\&K & 246 & 1417.80 & 35 & 130.59 & 5 & 6.65 \\
\hline 11 & Jharkhand & 103 & 208.95 & 6 & 4.05 & 8 & 34.85 \\
\hline 12 & Karnataka & 138 & 747.59 & 126 & 871.75 & 13 & 126.18 \\
\hline 13 & Kerala & 245 & 704.10 & 21 & 141.67 & 13 & 60.75 \\
\hline 14 & $\begin{array}{l}\text { Madhya } \\
\text { Pradesh }\end{array}$ & 299 & 803.64 & 11 & 86.16 & 3 & 4.90 \\
\hline 15 & Maharashtra & 255 & 732.63 & 45 & 281.33 & 21 & 7.00 \\
\hline 16 & Manipur & 114 & 109.13 & 8 & 5.45 & 3 & 2.75 \\
\hline 17 & Meghalaya & 101 & 229.80 & 4 & 31.03 & 3 & 1.70 \\
\hline 18 & Mizoram & 75 & 166.93 & 18 & 36.47 & 1 & 0.50 \\
\hline 19 & Nagaland & 99 & 188.98 & 10 & 28.67 & 4 & 4.20 \\
\hline 20 & Odisha & 222 & 295.47 & 9 & 64.30 & 4 & 3.60 \\
\hline 21 & Punjab & 237 & 393.23 & 46 & 154.50 & 12 & 21.15 \\
\hline 22 & Rajasthan & 66 & 57.17 & 10 & 23.85 & - & - \\
\hline 23 & Sikkim & 91 & 265.55 & 17 & 52.11 & 1 & 0.20 \\
\hline 24 & Tamil Nadu & 197 & 659.51 & 20 & 111.69 & & 18.00 \\
\hline 25 & Tripura & 13 & 46.86 & 3 & 16.01 & - & - \\
\hline 26 & Uttar Pradesh & 251 & 460.75 & 9 & 25.10 & - & - \\
\hline 27 & Uttarakhand & 444 & 1577.44 & 97 & 146.82 & 50 & 217.25 \\
\hline 28 & West Bengal & 203 & 396.11 & 23 & 98.40 & 17 & 84.25 \\
\hline 29 & A\&N Islands & 7 & 7.27 & 1 & 5.25 & - & - \\
\hline \multicolumn{2}{|c|}{ Total } & 5718 & 15384.15 & 864 & 3252.13 & 340 & 997.80 \\
\hline
\end{tabular}




\section{Biomass Components}

a) Lignin : $15-25 \%$

complex organic structure

Very high energy content

Structure hard, difficult to decompose

b) Hemicellulose : $23-32 \%$

Polymer of carbon $5 \& 6$ sugar

Easy to decompose

c) Cellulose : $38-50 \%$

polymer of glucose, very good biochemical

feedstock, Concrete (soft)

\section{Other Advantages}

As biomass is used to produce the biogas mainly but that there various other application of biogas which can be considered as the advantages of biomass according to its marvelous and efficient performance compared with other. The biogas is mainly used to produce electricity in India which is going to replace the coal for thermal power plant in future hence it is considered as great advantage corresponding to environmental issues. The other advantage is that the bio gas is also used for the cooking purpose which may replace the LPG in future. Then biomass is also used to generate the biodiesel for transportation purpose but the biodiesel is having some serious problems such as Lack of confidence in farmers due to the delay in notifying, publicizing and explaining the government biodiesel policy, no minimum support price. Again with the help of biomass we can make bioethanol but similar to the biodiesel bioethanol is also facing different problems. But the central government sets the policy regarding ethanol blending, but the State governments control the movement of molasses and often restrict molasses transport over State boundaries. Rather than above the main advantage is that the automatic pollution control and waste management.

\section{Biomass Energy in India}

India is a developing country at very fast rate hence the energy requirement in increasing in tremendous amount on other hand the pollution is also increasing in huge amount. By the use of biomass energy requirement of India can be easy fulfilled and it also helps in the waste management and pollution control. India produces about 450-500 million tons of biomass per year. Biomass provides $32 \%$ of all the primary energy use in the country at present. EAI estimates that the potential in the short term for power from biomass in India varies from about $18,000 \mathrm{MW}$, when the scope of biomass is as traditionally defined, to a high of about 50,000 MW if one were to expand the scope of definition of biomass. The current share of biofuels in total fuel consumption is extremely low and is confined mainly to $5 \%$ blending of ethanol in gasoline, which the government has made mandatory in 10 states. Currently, biodiesel is not sold on the Indian fuel market, but the government plans to meet $20 \%$ of the country's diesel requirements by 2020 using biodiesel. MNRE, Government of India, is administering a
MNRE-UNDP/GEF assisted project on "Removal of barriers to biomass power Generation in India". The objective is to increase the use of environmentally sustainable biomass power.

Table 2: Comparison of biomass with solar \& wind (Source : "21 Century by Biomass Energy", Sakai Masayasu)

\begin{tabular}{|l|l|l|l|}
\hline $\begin{array}{l}\text { Power } \\
\text { Generation }\end{array}$ & $\begin{array}{l}\text { Solar } \\
\text { Cell }\end{array}$ & Wind & Biomass \\
\hline $\begin{array}{l}\text { Total } \\
\text { Investment } \\
\text { (million US\$) }\end{array}$ & 1,830 & 12,700 & 6,300 \\
\hline $\begin{array}{l}\text { Facility Scale } \\
\text { (kW/year) }\end{array}$ & $1,000,000$ & $10,000,000$ & $10,000,000$ \\
\hline $\begin{array}{l}\text { Yearly } \\
\text { Operation } \\
\text { Rate (\%) }\end{array}$ & 12 & 20 & 70 \\
\hline $\begin{array}{l}\text { Yearly } \\
\text { Electricity } \\
\begin{array}{l}\text { Generation } \\
\text { (million kWh) }\end{array}\end{array}$ & 1,100 & 17,500 & 61,300 \\
\hline $\begin{array}{l}\text { Unit } \\
\text { Investment } \\
\text { US\$/kW) }\end{array}$ & 1.66 & 0.72 & 0.10 \\
\hline
\end{tabular}

\section{Future of Biomass in India}

India is a very fast growing and developing country and the industrialization and urbanization is increasing at very fast rate because of improvement in standard of living hence the power requirement is also increasing at tremendous rate. But according to present scenario India is not capable of delivering that power due to lack of sources of energy. So India is moving ahead toward the non-conventional energy sources to fulfill that energy requirement. As mention earlier that India is having the large sources for the biomass production which includes different types of wastes which are freely available in India at a large amount. The future of biomass is energy in India is very much bright due to the unlimited resources.

But due to lack of awareness and despite advancements in biomass energy technologies, most bioenergy consumption in India still remains confined to traditional uses. The modern technologies offer possibilities to convert biomass into synthetic gaseous or liquid fuels (like ethanol and methanol) and electricity. Lack of biomass energy market has been the primary barrier to the penetration of modern biomass technologies. Growing experience with modern biomass technologies in India suggests that technology push policies need to be substituted or augmented by market pull policies.

Future of biomass energy depends on providing reliable energy services at competitive cost. In India, this will happen only if biomass energy services can compete on a fair market. Policy priorities should be to orient biomass energy services towards market and to reform the market towards fair competition by internalizing the externalities of competing energy resources. Most economical option is utilization of waste materials. Potential availability of agro residues and wood processing waste in India can sustain 10,000 MW power. 


\section{CONCLUSION}

The biomass energy source is the best option for rural electrification. The biomass energy gives electricity, fertilizer, and green energy. This could help us to reduce the carbon footprint and reduce pollution.

India generates huge amounts of municipal waste. This could be used for generation of electricity and will help for better waste management.

Biomass energy is comparatively less costly as compared to other sources. Biogas production at rural level can empower the farmers and satisfy the demand for gas at consumer level itself. This can have huge impacts on the agriculture economy of India.

\section{ACKNOWLEDGEMENT}

All the statistical data and graphical data used in this paper belongs to their respective owners. The data have been represented here for research and educational purpose only.

\section{REFERENCES}

[1]. Sanke, Narsimhulu. "Biomass for power and energy generation." Combustion 900 (2008): 12000C.

[2]. Kumar, Anil, et al. "A review on biomass energy resources, potential, conversion and policy in India." Renewable and Sustainable Energy Reviews 45 (2015): 530539.

[3]. https://en.wikipedia.org/wiki/Biogas

[4].http://viridisperunding.com/services/renewable-energypower-plants/biogas-power-plants/

[5].http://www.lpgasmagazine.com/an-overview-of-biogas/

[6]. http://www.brighthub.com/environment/renewableenergy/articles/23762.aspx

\section{BIOGRAPHIES}

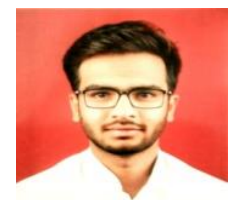

Shaikh Mohammed Shoeb is a student of final year engineering in electrical electronics and power studying at Jawaharlal Nehru Engg. College Aurangabad (M.S) INDIA Email-shoaibf265@gmail.com

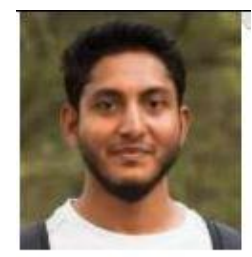

Shaikh Shoebis a student of final year engineering in electrical electronics and power studying at Jawaharlal Nehru Engg. College Aurangabad (M.S) INDIA

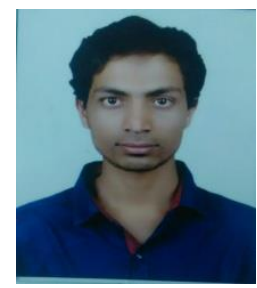

Mohammad Munwaroddinis a student of final year engineering in electrical electronics and power studying at Jawaharlal Nehru Engg. College Aurangabad (M.S) INDIA

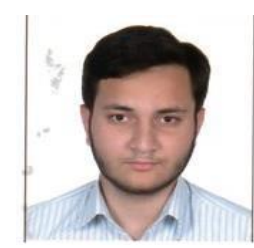

Syed Sibghatullah Quadriis a student of final year engineering in electrical electronics and power studying at Jawaharlal Nehru Engg. College Aurangabad (M.S) INDIA

Email: ssquadri195@gmail.com 